\title{
OXFORD EXPEDITIONS TO NORDAUSTLANDET (NORTH EAST LAND), SPITSBERGEN
}

\author{
H. R. Thompson*
}

A FOLLOWER of arctic exploration since 1920 cannot have failed to notice the very large number of expeditions organized by undergraduates of British universities. The pioneers in this movement were Oxford and Cambridge, which are still in the vanguard today. Whereas Cambridge is fortunate in possessing the Scott Polar Research Institute as well as a formidable number of senior polar experts, Oxford's work has received its stimulus through the purely local Oxford University Exploration Club and has always suffered from a lack of building and library facilities.

Nevertheless, the O.U.E.C. has eleven honorary and some one hundred life members, besides numerous temporary adherents. About twenty graduates and undergraduates attend the regular Club meetings and forty-five are listed as taking part in one or more expeditions in the period 1947-50 (O.U.E.C. Bull. No. 4, 1951). The regions visited in these four years are Jan Mayen, Iceland, Gambia, northwestern Scotland, western Ireland, Mount Kenya, Nordaustlandet, Gulf of Guinea, eastern Persia, and Finnmark. In 1951 parties visited Nordaustlandet and the Kiunga Archipelago (Kenya), while in 1952 a group penetrated as far as the Central Himalaya.

The Club has long been noted for its work in polar and mountainous areas. Perhaps this bias springs from the interests of its founders and of its present mentors, who include Charles Elton, Dr. K. S. Sandford, Professor Kenneth Mason, Professor A. C. Hardy, R. Scott Russell, Amyan Macfadyen, Dr. T. G. Longstaff, and the late Lord Tweedsmuir. Among the Oxford polar expeditions, five have visited Nordaustlandet, the second largest island in Spitsbergen (Fig. 1). It is with these parties, and their predecessors, that the following account is concerned.

Of non-Oxford expeditions (Fig. 2), Nordenskiöld's splendid thrust along the north coast and across the interior ice caps was hardly more than a pioneer reconnaissance, leaving no trace on present maps, apart from place names (Leslie, 1879). Koldewey's map of the extreme southwest (Koldewey, 1871) is correct as to details of terrain but somewhat inaccurate in its geographical relations. The survey of the west coast by the Russo-Swedish Arc of Meridian expedition (de Geer, 1923) is fairly accurate, except in one area (Thompson (B), unpubl.), and is rightly incorporated in modern charts. Except for Glen's party (discussed later), Ahlmann's Swedish-Norwegian expedition of 1931 was the most productive to visit Nordaustlandet (Ahlmann, 1933). Although little topographical surveying was attempted, detailed geological mapping was

${ }^{*}$ McGill University-Arctic Institute Carnegie Scholar in Geography, 1952-4. 
carried out in the northwest and intensive meteorological work was undertaken. Ahlmann himself made a most successful sledge journey across the three main ice caps, carrying out a preliminary survey of their levels and obtaining glaciological information which is still being put to significant use (Ahlmann, 1948). Mention must also be made of the air surveys carried out by Norwegian scientists in 1938 and 1948 (Luncke, 1949). While sometimes adding considerably to our detailed knowledge they have not everywhere been an improvement on existing ground surveys and are of course dependent on the latter for control points. Many other expeditions have produced maps of Nordaustlandet, most of them based on running surveys from ships, occasionally augmented by landings on coastal beaches ( $c f$. Parry, 1828; Petermann, 1872; Worsley, 1927). An interesting geographical account of the whole island is that of Dege (1946-7), the leader of a German wartime expedition.

It is remarkable that parties from Oxford University have done nearly all the rest of the work: they have carried out large-scale topographical and geological surveys of the north, east, and south coasts; they have made a large number of inland sledge journeys; they have included the only expedition to establish ice cap stations; and they have published an impressive collection of scientific papers (see Fig. 3 and References). The work of the five Oxford expeditions will now be considered in some detail, but since the two latest have so far failed to publish extensively, what follows must be treated as no more than a progress report.

\section{Binney, 1923}

The first Oxford party to reach Nordaustlandet was the Merton College expedition of 1923. Led by (Sir) George Binney, it included T. G. Longstaff (ornithologist), Charles Elton (ecologist), J. D. Brown (naturalist), and

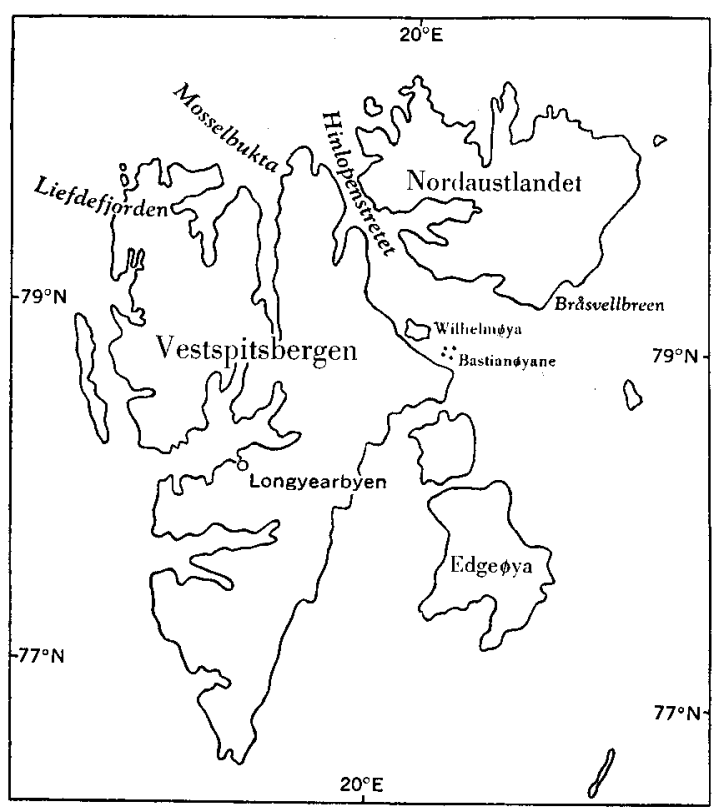

Fig. 1. Vestspitsbergen and Nordaustlandet. 


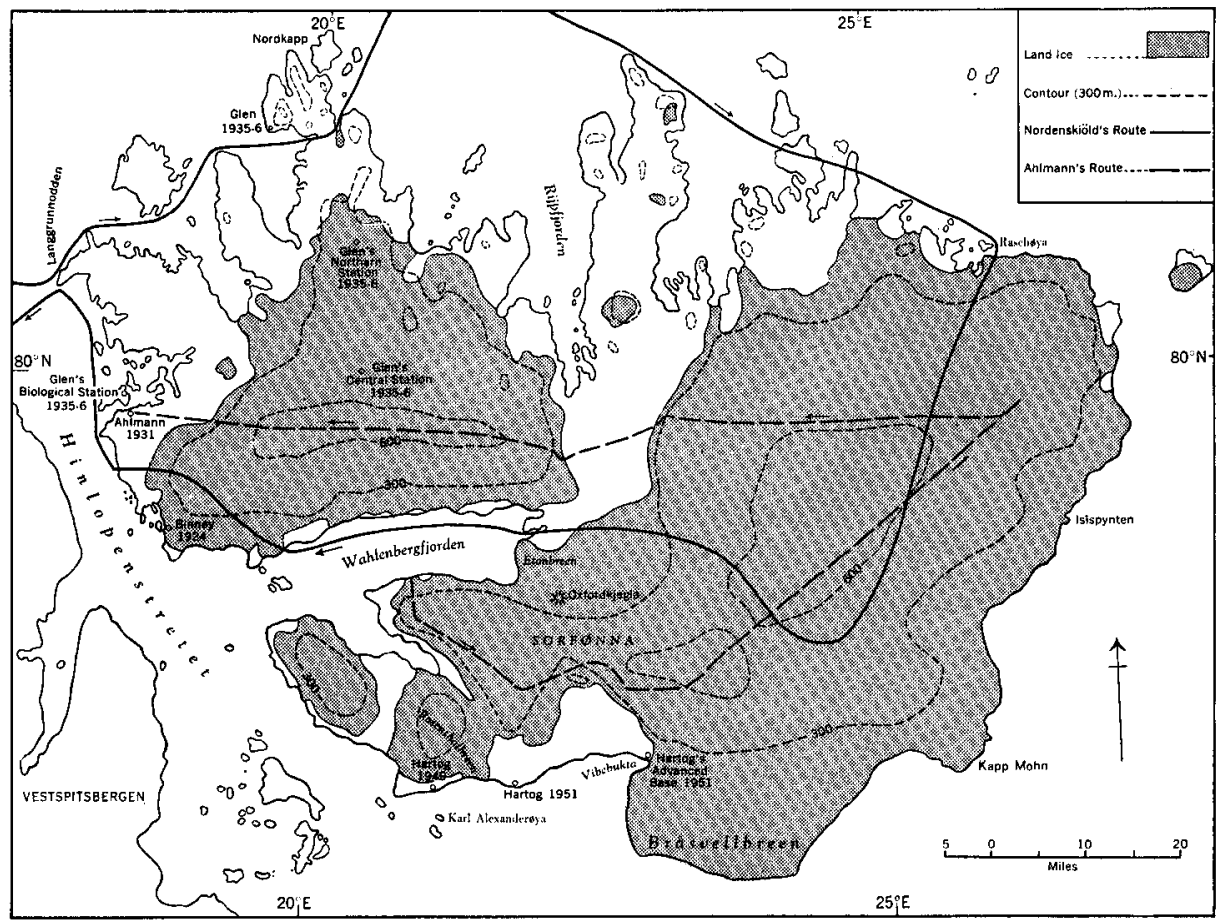

Fig. 2. General map of Nordaustlandet, showing sledge journeys of Nordenskiöld and Ahlmann.

E. Relf (physicist), as well as several handymen. The ship reached Hinlopenstretet on July 29 , but ice conditions were so bad that the sledge party ${ }^{1}$ intended for Nordaustlandet had to be landed in Vestspitsbergen instead.

The ship was forced aground and her propeller broken by floes but she managed to reach clear water south of Nordaustlandet. Two landings were made in Vibebukta on August 7, which resulted in the discovery of Carboniferous limestone and dolerite outcrops, and in botanical and zoological collections. Further eastward movement being blocked by ice, the ship sailed back to the northwest, passing close beside Karl Alexanderøya and the nearby mainland hills. The islet and the hills were reported by Elton-whose wide interests were of the greatest value to the expedition-to be of dolerite. A landing was made at the mouth of Wahlenbergfjorden and a few days later (August 11) another at Langgrunnodden.

Despite the failure of three attempts to replace the propeller, Binney now attempted to circumnavigate Nordaustlandet by the northern route. His bold attempt failed, but he got nearly as far east as Raschøya and was able to make a photographic survey of many headlands and islands. A final landing was made at Nordkapp on August 16, involving the feverish activity characteristic of such occasions.

${ }^{1}$ Comprising N. E. Odell (geologist), R. A. Frazer (surveyor), and A. C. Irvine and G. Milling (handymen). Odell and Irvine went to Mount Everest together the next year. 


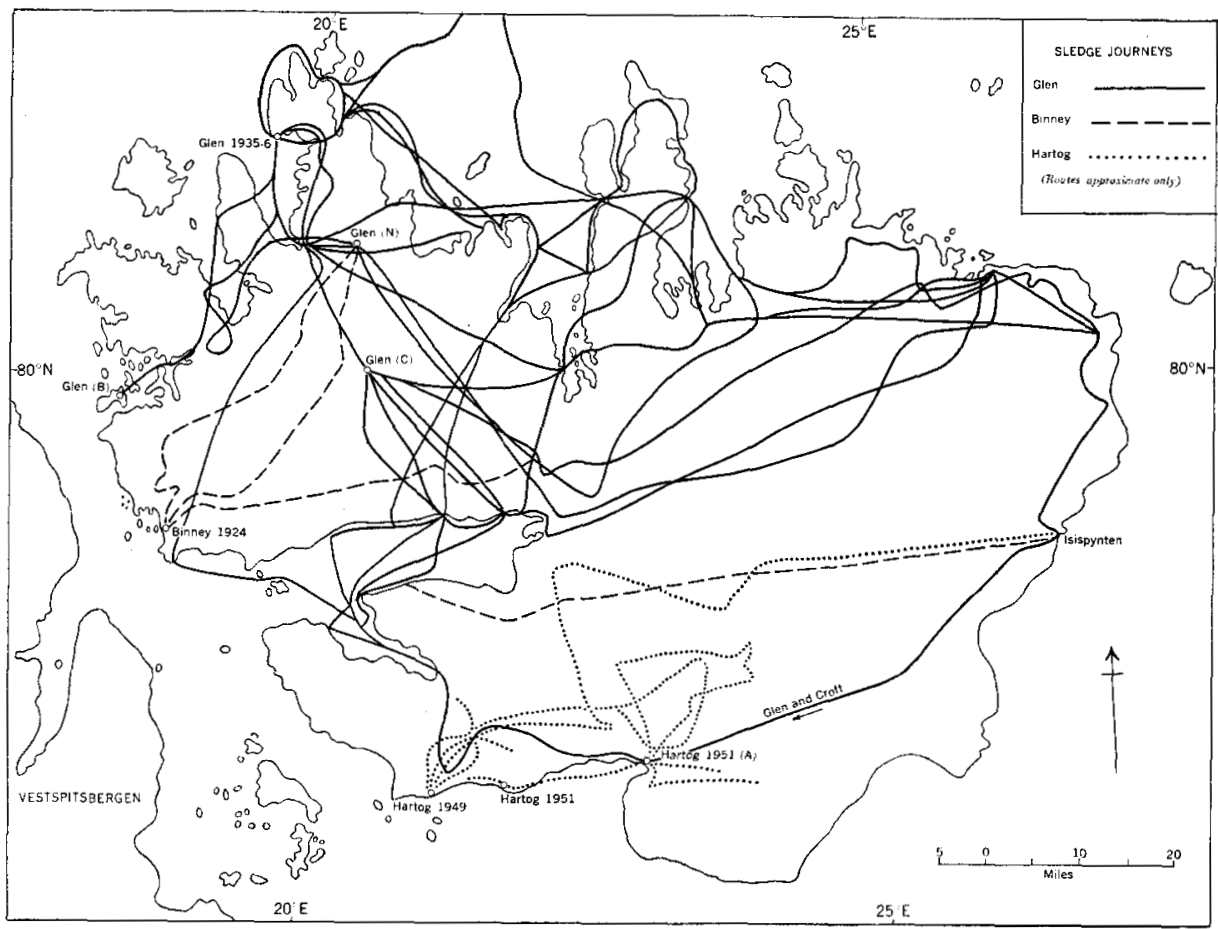

Fig. 3. Sledge routes of Oxford expeditions in Nordaustlandet. Sea trips and local journeys on foot are not included.

Although this expedition was not completely successful, the results were greater than might have been expected. A total of five landings was made on little known coasts. In addition to geological and botanical work, numerous corrections were sketched on the charts, nine magnetic stations were occupied, and full records were kept of animal life.

\section{Binney, 1924}

The greatest value of the 1923 expedition lay in the stimulus it gave Binney to try again. Deciding on larger-scale methods, in 1924 he employed two ships, three sledge parties, and a small seaplane. His team now included Charles Elton (ecologist), F. A. Montague (zoologist), K. S. Sandford (geologist), A. N. T. Rankin (bird photographer), E. Relf (physicist), (Sir) Howard Florey (medical officer), and R. A. Frazer, H. Baker, J. E. Tennant, and J. R. T. Aldous (surveyors). Notable amongst those with less specific duties were H. M. Clutterbuck, W. B. Carslake, and Helmer Hanssen of Amundsen's South Pole party. The seaplane was piloted by A. G. B. Ellis, with $\mathrm{F}$. Tymms as photographer.

The main base was established at Liefdefjorden in Vestspitsbergen on July 9, Binney and Ellis later having a narrow escape when the seaplane crashed. Proceeding eastwards, the ships put the northern and central sledge parties ashore at the mouth of Wahlenbergfjorden (Fig. 3) on July 21. After return- 
ing briefly to Vestspitsbergen in one ship while the other made a reconnaissance of ice conditions, Binney's southern party sailed along the south coast of Nordaustlandet and then up the east coast. Here the long stretch of ice cliffs was found to be broken by Isispynten (Isis Point), a spit of rock and moraine. The party landed on August 4 and sledged to Wahlenbergfjorden in ten days, mostly through unknown country. Meanwhile the central party had struck eastwards parallel to Wahlenbergfjorden, and the northern party had reached the future site of Glen's Northern Station. The discoveries of the three groups were predominantly concerned with the contours and micro-topography of the ice caps, about which very little was known. Nothing quite like Nordenskiöld's famous "ice canals" was found, but Sandford has given precise accounts of ice valleys whose headwalls were seamed with contour crevasses. The astonishingly severe melt season, which so hampered the sledging, provided Sandford with material for outstanding papers on weather, surfaces, and water erosion of the ice cap.

Sandford-whose part in this expedition was comparable to Elton's the previous year-also mapped the dolerite, limestone, and Hecla Hoek outcrops of Wahlenbergfjorden and elsewhere. Aldous provided a large-scale topographical survey for the geological map and Tymms photographed the northwest coast of the island from the seaplane. This was probably the first such use of aircraft in the polar regions and should not be discounted because of the otherwise dreary succession of accidents and bad weather.

The expedition left Wahlenbergfjorden on September 1 after spending six weeks in and around Nordaustlandet, during which a most impressive quantity of scientific material was obtained. But George Binney's greatest contribution lay in pure geographical discovery: he had revealed more of the character of Nordaustlandet than any predecessor. It was for later expeditions, aware of the broad setting, to pursue more detailed research.

\section{Glen, 1935-6}

Far and away the most productive group to visit Nordaustlandet was the Oxford University Arctic expedition led by A. R. Glen, a geographer and glaciologist with previous experience in Vestspitsbergen. His party consisted of Andrew Croft (second in command, photographer, and in charge of dogs), K. J. Bengtssen (trapper), R. A. Hamilton and R. Moss (physicists), D. B. Keith (biologist), A. B. Whatman (radio operator in charge of ionospheric research), and J. W. Wright, A. S. T. Godfrey, and A. Dunlop Mackenzie (surveyors). There was thus a strong emphasis on surveying and the physical sciences.

The main base was established in northwestern Nordaustlandet on 1 August 1935. Two ice cap stations were set up (Fig. 3), for the first time in Nordaustlandet. The Northern Station was in operation for four months and the Central Station for ten. Neither suffered any serious interruption of its thrice-daily meteorological records and both were comfortable and well equipped. Their chief purpose, other than meteorological, was to act as centres of glaciological research. The latter work, done mainly by Moss, 
included measurements of the vertical temperature gradient down to 22 metres, the rate of compression of firn, the rate of change from snow to firn to ice, the thermal conductivity of snow, firn, and ice, and the ablation-accumulation balance of the ice cap surface. The ice cap appeared to be of the Sub-polar type, in Ahlmann's geophysical classification. Glaciology of a more extensive kind was undertaken by Glen on the longer sledge journeys; in particular, the profile of the ice cap surface was measured by aneroid traverses and the height of the firn-line was determined by digging pits at frequent intervals.

At the main base Whatman carried out ionospheric research throughout the year. Diurnal fluctuations in the Heaviside and Appleton layers occurred regularly and the types of echo from the former appeared to have a greater range of variability than in lower latitudes. Atmospheric ozone and the aurora were also studied and measurements made of terrestrial magnetism and refraction. A record of sea-ice conditions was kept, both at the base and at the vantage point of the Northern Station. Glen and Croft reconnoitred the pack to nearly $81^{\circ} \mathrm{N}$.

The most spectacular feature of Glen's program was the ground survey, undertaken particularly by Wright. The intricacies of the north coast were fully unravelled for the first time in a high-quality triangulation from the main base to Raschøya. Most of this area was filled in by plane-table at a scale of 1:250,000. Meanwhile, plane-table surveys at 1:100,000 were being made on the bare land around and to the south of the base. At the same time, Aldous's 1924 survey of Wahlenbergfjorden was tied in with Wright's main triangulation. Glen and Croft's classic sledge journey around Nordaustlandet (Fig. 3) produced reconnaissance triangulations of the east and south coasts as well as some profiles of the ice cap surface.

In addition to all this Glen undertook detailed geological mapping on the north coast, finding an area in which Hecla Hoek sediments were flanked by large expanses of granite. The Hecla Hoek beds strike N-S and represent the northeastern limit of the ancient Caledonian fold system. Glen has also described the geomorphology of the regions he visited: for the south coast at least the notes are clear and accurate, despite the haste with which they were made, and have provided a solid foundation for subsequent work.

During the spring and summer of 1936 Keith and Godfrey maintained a biological station not far from Ahlmann's former base (Fig. 2). Here a special study was made of the "non-breeding" of some species of the bird population.

On 13 June 1936 Moss evacuated the buried and now-collapsing dome tent of the Central Station where he had spent ten months, several of them alone, and this exceptionally fruitful expedition came to an end with the arrival of the ship on August 21.

\section{Hartog, 1949}

In 1938, two years after Glen's sledge journey around Nordaustlandet, the pilot of a Norges Svalbard-og Ishavs Unders $\varnothing$ kelser survey aircraft discovered that a new glacier (Bråsvellbreen), derived from the inland ice, had appeared 
in the southeast of the island. A strongly crevassed glacier tongue, some two hundred square miles in area, extended beyond the old coastline. Because of the start of the war in 1939, no one studied this astonishing feature for ten years.

In 1949, however, John Hartog, chemist and glaciologist, led the first ground party to investigate Bråsvellbreen. His companions were J. L. Olsen (physicist and glaciologist), C. J. Harley (marine surveyor), W. ScottMoncrieff (surveyor), and the writer as geomorphologist. Although sea-ice conditions forced us to establish a base twenty miles to the west of Bråsvellbreen (Fig. 2), a sledge party surveyed the source area of that glacier (on the high ice cap), examined the structure of its surface layers, measured the height of its sea cliffs, and established that its seaward tongue must be aground. The enormous crevasses of the air photographs were found to have closed up under pressure from inland and to have been replaced by sub-parallel lines of ice-hummocks partially obscured by drifted snow.

Another manhauling sledge journey began at Isispynten. The exact position of this remote square mile of bare land was determined, and topographical and geological maps at a scale of 1:5,760 were made. The moraines, plants, and bird life were also investigated. From Isispynten Hartog travelled westwards to Etonbreen, carrying an aneroid traverse across the ice cap, searching in vain for Nordenskiöld's ice canals, and collecting rock specimens from Oxfordkjegla and from moraines near the south coast. Scott-Moncrieff and I undertook topographical, geological, and geomorphological surveys at a scale of $1: 31,680$, both to the east and to the west of Rosenthalbreen. The Triassic ${ }^{1}$ shales and Carboniferous limestones were shown to be flat-lying and most of the dolerite intrusions were proved to be sills. A reconnaissance geological survey was carried out on Karl Alexander $\varnothing y a$ (not previously visited) and this islet was linked with the mainland triangulation and with de Geer's triangulation point on Wilhelmøya.

The expedition's program also included a careful study of earlier maps of the region, the testing of equipment for hand-drilling in an ice cap, the description of sea-ice cover, and the recording of meteorological observations. These last showed a total precipitation of one inch and a mean temperature at sea level of $35^{\circ} \mathrm{F}$ for the period July 21 to August 17-the height of summer. Although limited by sea-ice conditions to seven weeks ashore and by money to man-hauling instead of dog-sledging, the 1949 Oxford expedition to Nordaustlandet made important contributions to our knowledge of the southern part of the island. It was the first expedition to establish its base on the south coast.

\section{Hartog, 1951}

Disappointed by his failure to establish the 1949 base beside Bråsvellbreen and anxious to study that glacier in greater detail, John Hartog organized a second expedition to Nordaustlandet in 1951. Arranged jointly with the Royal Navy and the Cambridge expedition to Vestspitsbergen, the latest Oxford party included W. Scott-Moncrieff (surveyor), M. F. W. Holland

${ }^{1}$ The southwesternmost shales may be of Jurassic age-the first rocks of this system to be identified in Nordaustlandet. (Personal communication from Dr. K. S. Sandford). 
(geomorphologist), J. T. Hollin and S. S. Wilson (glaciologists), and a detachment of five Royal Marines.

The expedition made a most successful but adventurous open-boat journey of 120 miles from Mosselbukta in Vestspitsbergen, down Hinlopenstretet, and so to the south coast of Nordaustlandet. They experienced much trouble with pack ice and the voyage took seven days, from July 11 to 18 . The frequent landings on islets enabled Holland to obtain useful geological information, particularly on the Carboniferous limestone.

The extent of the fast ice beside Bråsvellbreen and the necessity for finding a harbour for the whaleboats, once more forced Hartog to the west, though not as far as in 1949 (Fig. 3). A base was established on the shore and a series of weather observations was begun. Scott-Moncrieff extended his previous survey eastwards to Bråsvellbreen, while Hollin studied Rosenthalbreen, a small and decaying arm of the main ice cap. Holland continued my own geological and geomorphological work in the hinterland of Vibebukta, in a dreary landscape made up almost solely of Carboniferous limestone debris, but bearing a few interesting erratics.

Three tons of stores were man-hauled to an advanced base and a thermaldrilling site was established on the ice cap. Later other such sites were occupied on Bråsvellbreen, which proved to be a surprisingly cold glacier ${ }^{1}$. Ablation at the ice cap surface was measured and detailed sections across the Bråsvellbreen hummocks were run by two sledge parties. On another journey Hartog spent a week examining and mapping in detail the contact of Bråsvellbreen with the ice cap proper and fixed the highest point of Sørfonna (about 2,500 feet). These journeys, together with those in 1949, have determined the contours of the ice with precision.

The Marines used the whaleboats in making numerous soundings round the seaward tongue of Brassvellbreen. They also willingly helped with the sledging and took Scott-Moncrieff and Holland to Wilhelmøya and Bastian $\varnothing y a n e$ for triangulation and geological purposes.

In evacuating the advanced base late in August, a home-made wheeled trailer proved its worth on the raised beaches. The three whaleboats were navigated through pack ice to Mosselbukta in only 25 hours and a most enterprising season came to an end. Although nothing detailed has yet been published about this latest Oxford venture-the foregoing account is based on personal correspondence and consultations with Hartog-it is clear that the work of the 1949 party has been greatly strengthened and extended.

There will assuredly be more Oxford expeditions to Nordaustlandet. The greatest opportunities for a well-balanced party lie in the northeast of the island and in the territory southwest of Wahlenbergfjorden which has been bypassed for the last fifty years. Ice-covered southeastern Nordaustlandet offers wide scope for the glaciologist and the meteorologist but is a depressing prospect for anyone else.

${ }^{1 T h e}$ temperature was $-8.7^{\circ} \mathrm{C}$ at 25 feet below the surface and $-6.0^{\circ} \mathrm{C}$ at 75 feet. (Personal communication from S. S. Wilson). Cf. Glen, 1941, p. 145. 


\section{References}

This list is not intended to be complete. Many other papers on Binney's expeditions may be found in 'Spitsbergen papers' Vol. 2, and in 'Greenland and Spitsbergen papers', both published by the Oxford University Press. The writings of Glen and his companions remain scattered, but will eventually be collected in a similar manner. A series of vexatious delays has slowed down the preparation of Hartóg's results.

\section{General}

Ahlmann, H. W. and others. 1933. "Scientific results of the Swedish-Norwegian Arctic expedition in the summer of 1931". Geogr. Ann. Vol. 15, pp. 1-68, 73-216, and 261-348.

Ahlmann, H. W. 1948. 'Glaciological research on the North Atlantic coasts'. R.G.S. Research Ser. No. 1, 83 pp.

Dege, W. 1946-7. "Das Nordostland von Spitzbergen: Studien zu einer Landeskunde". Polarforscbung, Vol. 2, pp. 72-83 and 154-63.

De Geer, G. 1923. 'Topographie et géologie'. Mission suédoise, Mesure d'un arc de méridien au Spitzberg entreprises en 1899-1902, Vol. 2, Pt. 9, 36 pp.

Koldewey, K. 1871. 'Die erste deutsche Nordpolar-Expedition im Jahre 1868'. Petermann's Mitt. Ergänzungsheft, Vol. 6, No. 28, 56 pp.

Leslie, A. 1879. 'The arctic voyages of Adolf Erik Nordenskiöld'. London: $447 \mathrm{pp}$.

Luncke, B. 1949. 'Norges Svalbard- og Ishavs-unders $\varnothing$ kelsers kartarbeider og anvendelsen av skrå-fotogrammer tatt fra fly'. Norsk Polarinstitutt Medd. No. 68, $17 \mathrm{pp}$.

"Members of post-war expeditions". 1951. O. U. Explor. Club Bull. No. 4, p. 5.

Parry, W. E. 1828. 'Narrative of an attempt to reach the north pole. . . in the year 1827. London: xxiii $+229 \mathrm{pp}$.

Petermann, A. 1872. "Smyth's und Ulve's Entdeckungen und Aufnahmen im NordostLande". Petermann's Mitt. Vol. 18, pp. 104-6.

'The place-names of Svalbard'. 1942. Skrifter om Svalbard og Ishavet, No. 80, 539 pp.

Worsley, F. A. 1927. 'Under sail in the frozen north'. London: 295 pp.

\section{Binney, 1923 and 1924}

Binney, F. G. 1925. 'With seaplane and sledge in the Arctic'. London: 287 pp.

Binney, F. G. and others. 1925. "The Oxford University Arctic expedition, 1924". Geogr. J. Vol. 66, pp. 9-40 and 111-34. (Includes appendices on biology, geology and glaciology, meteorology, aerial navigation, magnetic observations, wireless, and aerial survey).

Elton, C. S. 1925. "The dispersal of insects to Spitsbergen". Trans. Entomol. Soc. Lond. Vol. 73 , pp. 289-99.

Frazer, R. A. and E. R. Relf. 1924. "Central Spitsbergen and North-East Land". Geogr. J. Vol. 64, pp. 193-213. (Concerns the 1923 expedition).

Sandford, K. S. 1926a. "The geology of North-East Land (Spitsbergen)". Q.J. Geol. Soc. Lond. Vol. 82, pp. 615-65.

1926b. "Summer in North-East Land, 1924: the climate and surface changes". Geogr. J. Vol. 68, pp. 200-25.

1929. "The glacial conditions and Quaternary history of North-East Land". Geogr. J. Vol. 74, pp. 451-70 and 543-52.

Summerhayes, V. S. and C. S. Elton. 1928. "Further contributions to the ecology of Spitsbergen". J. Ecol. Vol. 16, pp. 193-268.

Tymms, F. 1925. "Meteorological results of the Oxford University Arctic expedition". Met. Mag. Vol. 60, pp. 187-8.

Tyrrell, G. W. and K. S. Sandford. 1933. "Geology and petrology of the dolerites of Spitsbergen". Proc. Roy. Soc. Edinb. Vol. 53, pp. 284-321.

\section{Glen, 1935-6}

Glen, A. R. and N. A. C. Croft. 1937. 'Under the Pole Star'. London: 365 pp.

Glen, A. R. 1937. "The Oxford University Arctic expedition, North-East Land, 1935-36". Geogr. J. Vol. 90, pp. 193-222 and 289-314.

1938. "Sea ice conditions around North East Land during the year 19351936". Geogr. Ann. Vol. 20, pp. 152-69.

1939. "The glaciology of North East Land". Geogr. Ann. Vol. 21, pp. 1-35

1941. "A sub-arctic glacier cap: the West Ice of North East Land". Geogr J. Vol. 98, pp. 65-76 and $135-46$. 
Moss, R. 1938. "The physics of an ice-cap". Geogr. J. Vol. 92, pp. 211-31.

Sandford, K. S. 1950. "Observations on the geology of the northern part of North-East Land (Spitsbergen)". Q.J. Geol. Soc. Lond. Vol. 105, pp. 461-93. (Glen's geological results).

Wright, J. W. 1939. "Methods of survey in North East Land". Geogr. J. Vol. 93, pp. $210-27$.

\section{Hartog, 1949 and 1951}

(Hartog, J. M. and H. R. Thompson). 1950. "Oxford University expedition to North East Land, 1949". O.U. Explor. Club Bull. No. 3, pp. 5-10.

Hartog, J. M. and W. M. L. Wood. 1951. "Oxford and Cambridge explore". Geogr. Mag. Vol. 23, pp. 361-9.

Hollin, J. T. 1952. "Oxford and Cambridge expedition to North East Land, 1951: notes on equipment and methods". O. U. Explor. Club Bull. No. 5, pp. 14-9.

Thompson, H. R. 1952. "One square mile of ice: an experiment in geographical analysis". lll. Acad. Sci. Trans. Vol. 45, pp. 68-9.

1953. "Geology and geomorphology in southern Nordaustlandet (North-East Land), Spitsbergen". Proc. Geol. Assoc. Vol. 64, Pt. 4, pp. 293-312.

(A) Appendices on meteorology, geology, geomorphology, and glaciology. (Awaiting publication with Hartog's official narrative).

bergen". (Awaiting publication).

\section{INSTITUTE NEWS}

\section{'Arctic bibliography'}

The first three volumes of 'Arctic bibliography' have recently been published by the United States Government Printing Office. Preparation of the bibliography was begun in 1947 under an Office of Naval Research contract with the Arctic Institute. The project has been carried out with the joint support of the Department of the Army, the Department of the Navy, and the Department of the Air Force under the supervision of a directing committee. The Canadian Defence Research Board also contributed financially to the project.

These volumes are the result of four years' work, and it is believed that they contain sufficient material to meet the urgent requirement for a key to existing knowledge of the Arctic and to serve as a fundamental research tool. It is hoped that they will fill the long gap in arctic reference works since the publication of Chavenne's 'Literatur über die Polar-Regionen' in Vienna in 1878. Of necessity, the bibliography is incomplete and, as there is an ever present requirement to maintain it up-to-date, annual supplements are planned by the Directing Committee which will emphasize current publications and include such others as are particularly important to arctic research.

The Directing Committee, composed of librarians, scientists, and representatives of the military agencies and the Arctic Institute, determines policies and 